\title{
Synthesis of New Trimeric Lignin Model Compounds Containing 5-5' and $\beta-O-4$ ' Substructures, and their Characterization by 1D and 2D NMR Techniques
}

\author{
Vera L. Alves ${ }^{a}$, Mariza G. Drumond ${ }^{a}$, Guglielmo M. Stefani ${ }^{a}$, \\ Chen-Loung Chen ${ }^{b}$ and Dorila Piló-Veloso ${ }^{a_{*}}$ \\ ${ }^{a}$ Departamento de Química - ICEx - Universidade Federal de Minas Gerais, Belo Horizonte, MG, Brazil. \\ ${ }^{\mathrm{b}}$ Department of Wood and Paper Science, North Carolina State University, Raleigh, NC, USA.

\begin{abstract}
Os trímeros-modelo de lignina contendo as subestruturas bifenila (5-5') e aril-éter ( $\left.\beta-O-4^{\prime}\right)$ foram sintetizados a partir dos derivados da desidrodivanilina e da $\alpha$-bromo acetovanilona pela reação de Williamson. $\mathrm{O}$ estudo de $\mathrm{RMN}$ de ${ }^{1} \mathrm{H}$ e de ${ }^{13} \mathrm{C}$ destes trímeros foi feito utilizando as técnicas homo e heteronucleares. A atribuição dos sinais de $\mathrm{RMN}$ de ${ }^{1} \mathrm{H}$ e de ${ }^{13} \mathrm{C}$ e a conformação das moléculas são também discutidas neste artigo.
\end{abstract}

\begin{abstract}
Trimeric lignin model compounds containing biphenyl (5-5') and $\beta$-aryl ether ( $\left.\beta-O-4^{\prime}\right)$ were synthesized from dehydrodivanillin derivatives and $\alpha$-bromo acetovanillone derivatives via Williamson's reaction. The ${ }^{1} \mathrm{H}$ and ${ }^{13} \mathrm{C} \mathrm{NMR}$ characteristics of the resulting trimers were studied using corresponding ${ }^{1} \mathrm{H}$ and ${ }^{13} \mathrm{C}$ NMR spectra as well as homo- and heteronuclear 2D NMR techniques. The results are discussed in terms of signal assignment and conformation of the molecules.
\end{abstract}

Keywords: trimeric lignin model compounds, biphenyl substructure, $\beta$-aryl ether substructure, synthesis, 2D NMR spectroscopy

\section{Introduction}

Lignin is an integral component of wood consisting approximately one-third of the woody material in vascular plants. In general, lignin is removed in wood based industries, particularly in pulping processes in the pulp and paper industry, as by-products, usually burned in the recovery furnace to produce energy for mill operation. However, there is an increasing interest in its structural study because of its potential utilization as chemical feedstock in the chemical industry ${ }^{1,2}$.

In a previous study, Drumond et al. ${ }^{3}$ have shown that in milled wood lignin (MWL) from spruce wood, the frequency of 5-5' is approximately $24-26$ units per $100 \mathrm{C}_{9}$-units (phenylpropane units) ${ }^{1}$. These 5-5' units, consist mostly in the form of etherified 5-5' units, approximately $75 \%$ of the total and the remainder in the form of nonetherified units. Recently, Karhunen et al. ${ }^{4-6}$ showed that most of the etherified 5-5' units are present in the form of dibenzo- $2 \mathrm{H}, 3 \mathrm{H}-$ 1,4-dioxocin structure containing $\alpha-O-4$ ' and $\beta-O-4$ ' substructures. However, Ede and Kilpeläinen ${ }^{7}$ determined the amounts of $\alpha-O-4$ ' substructures in a number of soft- and hardwood MWLs by 2D NMR using inverse detection techniques. They concluded that these MWLs contain a total $\alpha-O-4$ ' unit of less than 0.3 units per $100 \mathrm{C}_{9}$-units ${ }^{1,8}$.
The objectives of this series of investigation are, therefore three-fold: (a) to synthesize trimeric lignin model compounds, (b) to study ${ }^{1} \mathrm{H}$ and ${ }^{13} \mathrm{C}$ NMR spectroscopic characteristics of this class of compounds, and finally (c) to compare these NMR spectroscopic characteristics to clarify the presence of these substructures in lignin.

In this work, we will report the synthesis and the NMR spectroscopic characteristics of new trimeric lignin model compounds containing both 5-5' and $\beta-O-4$ ' substructures ${ }^{1,3}$. These compounds include 4- $O$-acetyl-4' $-O$-[ $\alpha$-(3-methoxy4-ethoxyphenyl)- $\alpha$-oxoethyl]dehydrodivanillin (I), 4'- $O-[\alpha$ (3-methoxy-4-ethoxyphenyl)- $\alpha$-oxoethyl] dehydrodivanillin (II), 4'- $O$ - $[\alpha$-(3-methoxy-4-ethoxyphenyl)- $\alpha$-oxo- $\beta$ hydroxymethylethyl]dehydrodivanillin (III), 4'- $O$-[ $\alpha-(3-$ methoxy-4-ethoxyphenyl)- $\alpha$-hydroxyethyl] dehydrodivanillyl alcohol (IV) (Figure 1).

Compound I was prepared from 4-O-acetyldehydrodivanillin and $\alpha$-bromo-3-methoxy-4-ethoxyacetophenone via Williamson's reaction. Compounds II, III, and IV were obtained from I by base-catalyzed hydrolysis, hydroxymethylation with paraformaldehyde via aldol addition, and reduction, respectively. For the NMR studies DEPT, PENDANT, nOe difference, and 2D HMBC, ${ }^{1} \mathrm{H} /{ }^{1} \mathrm{H}-\mathrm{COSY}$ and ${ }^{1} \mathrm{H} /{ }^{13} \mathrm{C}-\mathrm{COSY}$ techniques were used to obtain the ${ }^{1} \mathrm{H}$ and ${ }^{13} \mathrm{C}$ NMR spectroscopic characteristics of the compounds. 
<smiles>CCOc1cc(C(C)=O)ccc1OC</smiles>

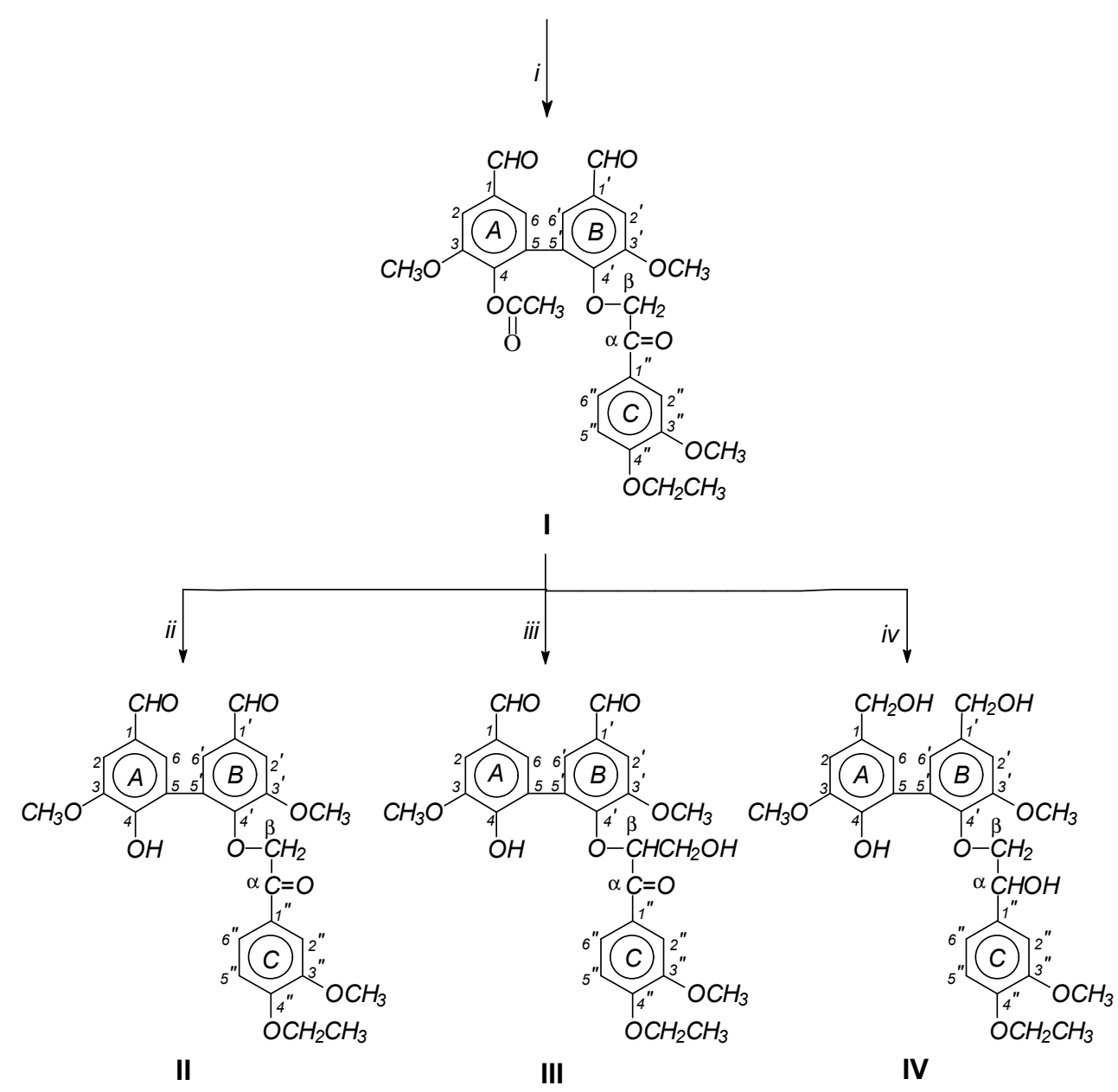

$i \mathrm{~K}_{2} \mathrm{CO}_{3}$, acetone, reflux; ii piperidine, $\mathrm{EtOH}$, reflux; iii para-formaldehyde, $\mathrm{DMF}$; iv $\mathrm{NaBH}_{4}, \mathrm{EtOH}$

Figure 1. Synthetic route for trimers I to IV.

\section{Experimental}

Melting points were determined on Mettler FT 80 melting point apparatus and are uncorrected. Elemental analysis were obtained on a Perkin Elmer 2400 apparatus. All NMR spectra were recorded on Bruker DRX 400 AVANCE spectrometer. Deuterated dimethyl-sulphoxide (DMSO- $d_{6}$ ) was used as solvent, and tetramethylsilane as internal reference. The pulse and acquisition conditions employed were: for ${ }^{1} \mathrm{H}^{1} \mathrm{H}-\mathrm{COSY} 45$ - dwell time (DW) $128.800 \mu \mathrm{s}$ (F1), acquisition time (AQ) $0.132 \mathrm{~s}$, number of transient (NS) 32, recycle delay (RD) $2.000 \mathrm{~s}$, time domain (TD) $1024(\mathrm{~F} 1)$,
TD 128 (F2); for PENDANT ${ }^{9}$ - DW $15.700 \mu \mathrm{s}$, AQ $1.029 \mathrm{~s}$, NS 10240, RD $1.000 \mathrm{~s}$, power level for composite pulse decoupling (PL-CPD) $28 \mathrm{~dB}, 1 / 4 \mathrm{JXH}$ (D4) $1.850 \mathrm{~ms}, 1 / 8 \mathrm{JXH}$ (D7) $4.620 \mathrm{~ms}$; for DEPT-135 - DW $15.700 \mu \mathrm{s}$, AQ $1.029 \mathrm{~s}$, NS 2048, RD $1.500 \mathrm{~s}$, delay for antiphase magnetization (D2) $3.571 \mathrm{~ms}$; for nOe differential - DW $60.800 \mu \mathrm{s}$, AQ $3.985 \mathrm{~s}$, NS 180, RD $2.000 \mathrm{~s}$, TD 65.536, power level for

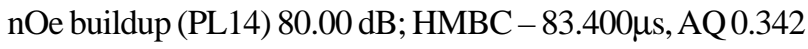
$\mathrm{s}$, NS 16, RD $2.000 \mathrm{~s}$, delay for long range coupling (D6) $0.070 \mathrm{~s}, \mathrm{TD} 4096$ (F2) and 1024 (F1). 4-O-acetyldehydrodivanillin was prepared as described in the literature ${ }^{10}$, and so was $\alpha$-bromo-3-methoxy-4-ethoxyacetophenone ${ }^{11}$. 


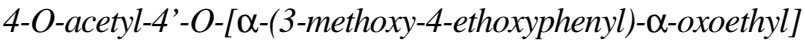
dehydrodivanillin (I)

To a solution of $\alpha$-bromo-3-methoxy-4-ethoxyacetophenone $(0.19 \mathrm{~g}, 0.71 \mathrm{mmol})$ and $4-O$-acetyldehydrodivanillin $(0.29 \mathrm{~g}, 0.84 \mathrm{mmol})$ in $12 \mathrm{~mL}$ of dried acetone, anhydrous potassium carbonate $(0.18 \mathrm{~g}, 1.3 \mathrm{mmol}$ ) was added. The mixture was refluxed under magnetic stirring for $1 \mathrm{hr}$. The insolubles were filtered off and the solvent was reduced under vacuum to give a residue that was dissolved in chloroform and washed with $0.5 \mathrm{~mol} \mathrm{~L}^{-1}$ $\mathrm{NaOH}$ solution. The organic layer was dried over anhydrous $\mathrm{Na}_{2} \mathrm{SO}_{4}$, and the solvent was removed under reduced pressure. The product was precipitated by addition of tetrahydrofuran-hexane mixture to the resulting solution to give a yellow solid $(0.28 \mathrm{~g}, 73 \%)$, mp. $75-78{ }^{\circ} \mathrm{C}$. Anal. Calcd for $\mathrm{C}_{29} \mathrm{H}_{28} \mathrm{O}_{10}$, C: 64.93, H: 5.22. Found: C: 64.80, H: 5.20. ${ }^{1} \mathrm{H}$ NMR [(400 MHz, DMSO- $\left.d_{6}\right) \delta 1.36(\mathrm{t}$, $J 6.95 \mathrm{~Hz}, 3 \mathrm{H}), 2.10$ (s, $3 \mathrm{H}), 3.92(\mathrm{~s}, 3 \mathrm{H}), 3.82(\mathrm{~s}, 3 \mathrm{H}), 3.79$ (s, $3 \mathrm{H}), 4.10$ (q, J6.95 Hz, $2 \mathrm{H}), 5.34$ (s, $2 \mathrm{H}), 7.57$ (d, J 1.65 $\mathrm{Hz}, 1 \mathrm{H}), 7.60$ (d, J $1.75 \mathrm{~Hz}, 1 \mathrm{H}), 7.33(\mathrm{~d}, J 1.93 \mathrm{~Hz}, 1 \mathrm{H})$, $6.97(\mathrm{~d}, J 8.45 \mathrm{~Hz}, 1 \mathrm{H}), 7.55(\mathrm{~d}, J 1.65 \mathrm{~Hz}, 1 \mathrm{H}), 7.38(\mathrm{~d}, J$ $1.75 \mathrm{~Hz}, 1 \mathrm{H}), 7.47$ (dd, $J 1.93$ and $8.45 \mathrm{~Hz}, 1 \mathrm{H}), 9.94$ $(\mathrm{s}, 1 \mathrm{H}), 9.92(\mathrm{~s}, 1 \mathrm{H}) .{ }^{13} \mathrm{C}$ NMR $\left(100 \mathrm{MHz}\right.$, DMSO- $\left.d_{6}\right)$ $\delta$ 15.6, 21.0, 56.3, 57.0, 57.1, 64.8, 75.0, 111.1, 111.6, 113.3, 112.4, 123.3, 126.3, 126.6, 127.8, 130.0, 132.3, 132.9, 135.1, 143.0, 149.4, 150.0, 152.6, 153.4, 192.4, 192.7, 193.1.

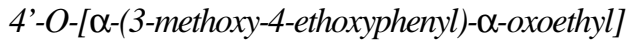
dehydrodivanillin (II)

A mixture of $\mathbf{I}(0.076 \mathrm{~g}, 0.14 \mathrm{mmol})$, toluene $(0.2 \mathrm{~mL})$, piperidine $(0.1 \mathrm{~mL})$ and $95 \% \mathrm{EtOH}(1 \mathrm{~mL})$ was refluxed under magnetic stirring for $30 \mathrm{~min}$. The mixture was neutralized with $\mathrm{AcOH}$, and $5 \mathrm{~mL} \mathrm{H}_{2} \mathrm{O}$ was added to the solution. The resulting aqueous solution was extracted with $\mathrm{CHCl}_{3}$. The organic layer was dried over anhydrous $\mathrm{Na}_{2} \mathrm{SO}_{4}$ and the solvent was removed under reduced pressure. The product was precipitated by addition of petroleum ether to the resulting solution to give a yellow solid $(0.039 \mathrm{~g}, 55 \%)$, mp. 133.6-136. ${ }^{\circ} \mathrm{C}$ ). Anal. Calcd for $\mathrm{C}_{27} \mathrm{H}_{26} \mathrm{O}_{9}, \mathrm{C}: 65.59$, H: 5.26. Found: C: 65.39, H: 5.24. ${ }^{1} \mathrm{H}$ NMR [ $(400 \mathrm{MHz}$, DMSO- $\left.d_{6}\right) \delta 1.34(\mathrm{t}, J 6.90 \mathrm{~Hz}, 3 \mathrm{H}), 3.88(\mathrm{~s}, 3 \mathrm{H}), 3.82(\mathrm{~s}, 3$ H), $3.76(\mathrm{~s}, 3 \mathrm{H}), 4.10(\mathrm{q}, J 6.90 \mathrm{~Hz}, 2 \mathrm{H}), 5.29(\mathrm{~s}, 2 \mathrm{H}), 7.39$ $(\mathrm{d}, J 1.88 \mathrm{~Hz}, 1 \mathrm{H}), 7.54(\mathrm{~d}, J 1.92 \mathrm{~Hz}, 1 \mathrm{H}), 7.30(\mathrm{~d}, J 1.99 \mathrm{~Hz}$, $1 \mathrm{H}), 6.95(\mathrm{~d}, J 8.28 \mathrm{~Hz}, 1 \mathrm{H}), 7.36(\mathrm{~d}, J 1.88 \mathrm{~Hz}, 1 \mathrm{H}), 7.45(\mathrm{~d}$, $J 1.92 \mathrm{~Hz}, 1 \mathrm{H}), 7.44(\mathrm{dd}, J 1.99$ and $8.28 \mathrm{~Hz}, 1 \mathrm{H}), 9.74(\mathrm{~s}, 1$ $\mathrm{H}), 9.92(\mathrm{~s}, 1 \mathrm{H}), 9.98\left(1 \mathrm{H}\right.$, exchange with $\left.\mathrm{D}_{2} \mathrm{O}\right) .{ }^{13} \mathrm{C}$ NMR $\left(100 \mathrm{MHz}, \mathrm{DMSO}-d_{6}\right) \delta 14.5,55.4,55.9,56.0,63.9,74.2$, 109.2, 110.1, 111.3, 111.4, 122.5, 124.4, 125.4, 126.6, 127.8, 128.0, 131.0, 131.6, 147.7, 148.0, 148.5, 150.2, 150.3, 152.5, 191.0, 191.7, 192.4 .

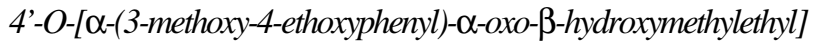
dehydrodivanillin (III)

A solution of $\mathbf{I}(0.10 \mathrm{~g}, 0.18 \mathrm{mmol})$, paraformaldehyde $(0.026 \mathrm{~g}, 0.3 \mathrm{mmol})$ and $\mathrm{NaOH}(0.0076 \mathrm{~g})$ in $5.5 \mathrm{~mL}$ of DMF was stirred on an oil bath at $60^{\circ} \mathrm{C}$ under a $\mathrm{N}_{2}$ atmosphere for $12 \mathrm{~h}$. The reaction mixture was then poured into $10 \mathrm{~mL}$ of ice-cooled water. The precipitate was filtered off, and the aqueous layer was extracted with $\mathrm{CHCl}_{3}$, and the solvent was removed under reduced pressure. The product was precipitated by addition of ice-cooled water into the resulting solution to give a beige solid $(0.010 \mathrm{~g}, 10 \%), \mathrm{mp}$. 91-94 ${ }^{\circ} \mathrm{C}$. Anal. Calcd for $\mathrm{C}_{28} \mathrm{H}_{28} \mathrm{O}_{10}$, C: 64.12, H: 5.34. Found: C: 63.91, H: 5.33. ${ }^{1} \mathrm{H}$ NMR [ [(400 MHz, DMSO- $\left.d_{6}\right)$ $\delta 1.36(\mathrm{t}, J 7.00 \mathrm{~Hz}, 3 \mathrm{H}), 3.88(\mathrm{~s}, 3 \mathrm{H}), 3.61(\mathrm{~s}, 3 \mathrm{H}), 3.75(\mathrm{~s}$, $3 \mathrm{H}), 4.10$ (q, J 7.00 Hz, $2 \mathrm{H}), 4.81$ (d, J $5.80 \mathrm{~Hz}, 2 \mathrm{H}), 4.87$ $\left(\mathrm{s}, 1 \mathrm{H}\right.$, exchange with $\left.\mathrm{D}_{2} \mathrm{O}\right), 5.54(\mathrm{t}, J 5.80 \mathrm{~Hz}, 2 \mathrm{H}), 7.43$ $(\mathrm{d}, J 2.00 \mathrm{~Hz}, 1 \mathrm{H}), 7.46(\mathrm{~d}, J 2.00 \mathrm{~Hz}, 1 \mathrm{H}), 7.58(\mathrm{~d}, J 1.90$ $\mathrm{Hz}, 1 \mathrm{H}), 7.30$ (d, J $1.80 \mathrm{~Hz}, 1 \mathrm{H}), 6.97(\mathrm{~d}, J 8.20 \mathrm{~Hz}, 1 \mathrm{H})$, $7.33(\mathrm{~d}, J 1.90 \mathrm{~Hz}, 1 \mathrm{H}), 7.50(\mathrm{dd}, J 1.80$ and $8.20 \mathrm{~Hz}, 1 \mathrm{H})$, $9.73(\mathrm{~s}, 1 \mathrm{H}), 9.89(\mathrm{~s}, 1 \mathrm{H}), 9.96\left(1 \mathrm{H}\right.$, exchange with $\left.\mathrm{D}_{2} \mathrm{O}\right)$. ${ }^{13} \mathrm{C}$ NMR $\left(100 \mathrm{MHz}, \mathrm{DMSO}-d_{6}\right) \delta 15.6,21.0,56.3,57.0$, 57.1, 64.8, 75.0, 109.2, 110.1, 111.3, 123.2, 124.0, 127.0, 127.6, 127.8, 128.6, 130.3, 131.0, 140.8, 148.3, 150.1, 150.2, 151.4, 152.3, 192.4, 192.7, 193.1 .

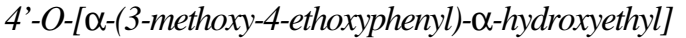 dehydrodivanillylalcohol (IV)}

To a solution of $\mathbf{I}(0.10 \mathrm{~g}, 0.18 \mathrm{mmol})$ in $2 \mathrm{~mL} \mathrm{CHCl}_{3}$ and $3 \mathrm{~mL} 95 \% \mathrm{EtOH}, \mathrm{NaBH}_{4}(0.051 \mathrm{~g}, 1.35 \mathrm{mmol})$ was added. The solution was stirred at room temp. for $24 \mathrm{~h}$. The reaction mixture was then acidified and extracted with $\mathrm{CH}_{2} \mathrm{Cl}_{2}$. The organic layer was dried over anhydrous $\mathrm{Na}_{2} \mathrm{SO}_{4}$, and the solvent was removed under reduced pressure. The product was precipitated by addition of hexane to the resulting mixture to give a beige solid $(0.047 \mathrm{~g}$, $51 \%$, mp. 70-74.1 ${ }^{\circ} \mathrm{C}$ ). Anal. Calcd for $\mathrm{C}_{27} \mathrm{H}_{32} \mathrm{O}_{9}, \mathrm{C}: 64.80$, H: 6.40. Found: C: 64.59, H: 6.42. ${ }^{1} \mathrm{H}$ NMR [ $(400 \mathrm{MHz}$, DMSO- $\left.d_{6}\right) \delta 1.26(\mathrm{t}, J 7.00 \mathrm{~Hz}, 3 \mathrm{H}), 3.81(\mathrm{~s}, 3 \mathrm{H}), 3.82(\mathrm{~s}$, $3 \mathrm{H}), 3.68$ (s, $3 \mathrm{H}), 3.89-3.95(\mathrm{~m}, 4 \mathrm{H}), 4.38-4.43(\mathrm{~m}, 3 \mathrm{H})$, 4.90-5.30 (m, $3 \mathrm{H}$, exchange with $\left.\mathrm{D}_{2} \mathrm{O}\right), 6.64-7.74(\mathrm{~m}, 7$ $\mathrm{H}), 9.60\left(1 \mathrm{H}\right.$, exchange with $\left.\mathrm{D}_{2} \mathrm{O}\right) .{ }^{13} \mathrm{C}$ NMR $(100 \mathrm{MHz}$, DMSO- $\left.d_{6}\right) \delta 14.7,55.3,55.7,55.8,62.6,62.7,63.7,71.3$, 78.0, 109.4, 110.1, 110.3, 113.1, 118.6, 121.0, 121.1, $125.5,132.2,132.5,134.8,137.3,142.4,144.5,146.9$, $147.5,149.0,151.8$.

\section{Results and Discussion}

The chemical shift assignments and coupling constants for I and II (Table 1) were deduced from 1D NMR spectra, 
Table 1. ${ }^{1} \mathrm{H}$ Chemical Shifts $(\delta)$ of trimers I and II

\begin{tabular}{|c|c|c|c|c|c|c|}
\hline \multicolumn{2}{|l|}{ Trimer } & \multicolumn{2}{|l|}{ I } & \multicolumn{2}{|c|}{ II } & \multirow[b]{2}{*}{$J(\mathrm{~Hz})$} \\
\hline Group & $\delta$ & Multip. & $J(\mathrm{~Hz})$ & $\delta$ & Multip. & \\
\hline $\mathrm{OCH}_{2} \mathrm{CH}_{3}$ & 1.36 & $\mathrm{t}$ & 6.95 & 1.34 & $\mathrm{t}$ & 6.90 \\
\hline $\mathrm{CH}_{3} \mathrm{COO}$ & 2.10 & $\mathrm{~s}$ & & & & \\
\hline $\mathrm{OC} \underline{H}_{3}-\mathrm{A}$ & 3.92 & $\mathrm{~s}$ & & 3.88 & s & \\
\hline $\mathrm{OC} \underline{\mathrm{H}}_{3}-\mathrm{B}$ & 3.82 & s & & 3.82 & s & \\
\hline $\mathrm{OCH}_{3}-\mathrm{C}$ & 3.79 & $\mathrm{~s}$ & & 3.76 & s & \\
\hline $\mathrm{OCH}_{2} \mathrm{CH}_{3}$ & 4.10 & $q$ & 6.95 & 4.10 & $q$ & 6.90 \\
\hline $\mathrm{OC}_{2}{ }_{2} \mathrm{CO}$ & 5.34 & s & & 5.29 & s & \\
\hline $\mathrm{H}-2-\mathrm{A}$ & 7.57 & $\mathrm{~d}$ & 1.65 & 7.39 & d & 1.88 \\
\hline H-2 - B & 7.60 & $\mathrm{~d}$ & 1.75 & 7.54 & $\mathrm{~d}$ & 1.92 \\
\hline $\mathrm{H}-2-\mathrm{C}$ & 7.33 & d & 1.93 & 7.30 & d & 1.99 \\
\hline $\mathrm{H}-5-\mathrm{C}$ & 6.97 & d & 8.45 & 6.95 & d & 8.28 \\
\hline H-6 - A & 7.55 & $\mathrm{~d}$ & 1.65 & 7.36 & $\mathrm{~d}$ & 1.88 \\
\hline H-6 - B & 7.38 & $\mathrm{~d}$ & 1.75 & 7.45 & d & 1.92 \\
\hline $\mathrm{H}-6-\mathrm{C}$ & 7.47 & dd & 1.93 and 8.45 & 7.44 & dd & 1.99 and 8.28 \\
\hline $\mathrm{CHO}-\mathrm{A}$ & 9.94 & s & & 9.74 & s & \\
\hline $\mathrm{CHO}-\mathrm{B}$ & 9.92 & s & & 9.92 & s & \\
\hline
\end{tabular}

Multip.= Multiplicities $\left(400 \mathrm{MHz}, \mathrm{DMSO}-d_{6}\right)$

Table 2. H/C correlations $\left({ }^{3} J_{\mathrm{CH}}\right)$ for model compound I using HMBC technique

\begin{tabular}{|c|c|c|c|}
\hline$\delta{ }^{1} \mathrm{H}$ & $\mathrm{H}$ & Ring & $\mathrm{C}\left(\delta^{13} \mathrm{C}\right)$ \\
\hline 9.94 & $\mathrm{CHO}$ & A & C-2 (111.6) and C-6 (126.6) \\
\hline 7.57 & $\mathrm{H}-2$ & A & C-4 (143.0), C-6 (126.6) and CHO (192.7) \\
\hline 7.55 & H-6 & A & C-2 (111.6) and C-4 (143.0) \\
\hline 9.92 & $\mathrm{CHO}$ & B & C-2 (113.3) and C-6 (126.3) \\
\hline 7.60 & $\mathrm{H}-2$ & B & C-6 (126.3), C-4 (152.6) and CHO (192.4) \\
\hline 7.38 & H-6 & B & C-2 (113.3), C-4 (152.6) and CHO (192.4) \\
\hline 7.33 & $\mathrm{H}-2$ & $\mathrm{C}$ & C-4 (153.4), C-6 (123.3) and CO (193.1) \\
\hline 6.97 & $\mathrm{H}-5$ & $\mathrm{C}$ & C-3 (149.5) and C-1 (130.0) \\
\hline 7.47 & H-6 & $\mathrm{C}$ & C-2 (111.1) and C-4 (153.4) \\
\hline 5.34 & $\mathrm{CH}_{2}-\beta$ & $\mathrm{B} / \mathrm{C}$ & $\mathrm{C}-4 / \mathrm{B}(152.6)$ and $\mathrm{C}-1 / \mathrm{C}(130.0)$ \\
\hline
\end{tabular}

and confirmed by ${ }^{1} \mathrm{H} /{ }^{1} \mathrm{H}-\mathrm{COSY}, \mathrm{HMBC}$ and nOe difference spectra. For example, for compound $\mathbf{I}$ : the ${ }^{1} \mathrm{H}$ resonances at $\delta 7.33$ (doublet, $J 1.93 \mathrm{~Hz}$ ), 6.97 (doublet, $J 8.45 \mathrm{~Hz}$ ) and 7.47 (double doublet $J 1.93$ and $8.45 \mathrm{~Hz}$ ) indicate the three spin system of ring $\mathrm{C}$ and were confirmed by HMBC technique (Table 2) and nOe difference spectra (Table 3).

The HMBC data confirmed the aromatic and formyl hydrogen chemical shifts for rings A and B. Hence, Table 2 data show that methylene at $\delta 5.34$ ( $\beta$ to $B$ and $C$ ) as well as both $\mathrm{H}-2$ at $\delta 7.60$ and H-6 at $\delta 7.38$ are correlated with $\mathrm{C}-4$ at $\delta$ 152.6. These correlations confirm ring B hydrogen assignments. $\mathrm{H}-2$ at $\delta 7.60$ also correlates with formyl carbon at $\delta 192.4$ and C- 6 at $\delta 126.3$. Once the hydrogen chemical shifts for rings $\mathrm{B}$ and $\mathrm{C}$ were assigned, the remaining ones were attributed to ring A. Finally, $\mathrm{H}-2$ at $\delta 7.57$ shows correlation with formyl group of ring $A$ at $\delta$ 192.7.

The nOe difference spectra are useful in establishing molecular conformation and steric arrangement of substituents. Therefore, spectra obtained by using these techniques were used to verify the conformation of $\mathbf{I}$ (Table 3).
Table 3. Interpretation of nOe difference spectra* of trimer I

\begin{tabular}{cc}
\hline$\delta$ Irradiation $(\mathrm{H} / \mathrm{Ring})$ & $\begin{array}{c}\delta \text { Observed Nuclear Overhauser } \\
\text { Enhancements }(\mathrm{H} / \mathrm{Ring})\end{array}$ \\
\hline $9.92(\mathrm{CHO} / \mathrm{B})$ & 7.38 and $7.60(\mathrm{H}-6$ and $\mathrm{H}-2 / \mathrm{B})$ \\
$7.38(\mathrm{H}-6 / \mathrm{B})$ & $9.92(\mathrm{CHO})$ \\
$9.94(\mathrm{CHO} / \mathrm{A})$ & 7.55 and $7.57(\mathrm{H}-6$ and $\mathrm{H}-2 / \mathrm{A})$ \\
$3.92\left(\mathrm{OCH}_{3} / \mathrm{A}\right)$ & $7.57(\mathrm{H}-2 / \mathrm{A})$ \\
$7.33\left(\mathrm{H}^{2} / \mathrm{C}\right)$ & $3.79\left(\mathrm{OCH}_{3} / \mathrm{C}\right)$ and $5.34(\mathrm{OCH} 2 \mathrm{CO})$ \\
$4.10\left(\mathrm{CH}_{2} \mathrm{CH}_{3}\right)$ & $6.97(\mathrm{H}-5 / \mathrm{C})$ and $1.36\left(\mathrm{CH}_{2} \mathrm{CH}_{3}\right)$ \\
$3.82\left(\mathrm{OCH}_{3} / \mathrm{B}\right)$ & $7.60(\mathrm{H}-2 / \mathrm{B})$ \\
$5.34\left(\mathrm{OCH}_{2} \mathrm{CO}\right)$ & $7.33(\mathrm{H}-2 / \mathrm{C})$ and $7.47(\mathrm{H}-6 / \mathrm{C})$
\end{tabular}

*at $400 \mathrm{MHz}$ in DMSO-d 6

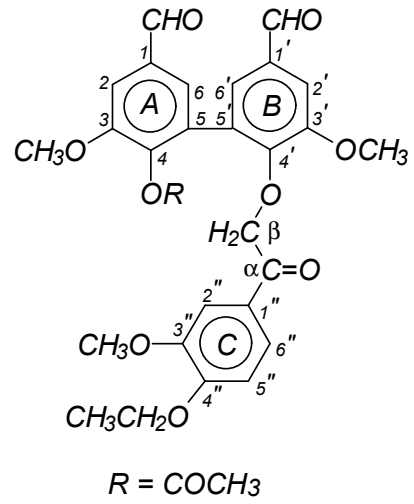

Irradiation of $\mathrm{OCH}_{2} \mathrm{CO}$ hydrogens at $\delta 5.34$ enhances the signals of H-2" at $\delta 7.33$ and H-6" at $\delta 7.47$, both aromatic hydrogens in the ring $\mathrm{C}$ of compound $\mathbf{I}$, while the intensity of the signal at $\delta 3.82$, corresponding to hydrogens of methoxy group in ring $\mathrm{B}$, was not affected. This last observation shows that the $\mathrm{C}_{4},-\mathrm{O}$ bond is not free to rotate. On the other hand, irradiation of the methoxyl group resonance at $\delta 3.82$ only enhances the signal at $\delta 7.60$ corresponding to $\mathrm{H}-2$ ' of ring B. 
These results show that the 3-methoxy-4-ethoxyphenacyl group is syn to ring $\mathrm{A}$ and also that ring $\mathrm{C}$ is rotating about $\mathrm{C}_{\alpha}-\mathrm{C}_{1}$, bond. In addition, the analysis of nOe difference spectra has allowed to assign unambiguously the chemical shifts of hydrogens and methoxy groups of each aromatic ring (Table 3).

From broadband decoupled ${ }^{13} \mathrm{C}$ NMR and DEPT spectra of compound $\mathbf{I}$, the signals for aliphatic carbons at $\delta$ $15.6\left(\mathrm{OCH}_{2} \mathrm{CH}_{3}\right), 21.0\left(\mathrm{CH}_{3} \mathrm{COO}\right)$, 56.3, 57.0 and 57.1 $\left(\mathrm{OCH}_{3}\right), 64.8\left(\mathrm{OCH}_{2} \mathrm{CH}_{3}\right), 75.0\left(\mathrm{CH}_{2}-\beta\right), 192.4$ and 192.7 (CHO), and 193.1 (CO) were assigned.

In ${ }^{13} \mathrm{C}$ NMR spectrum of trimer II, obtained by PENDANT pulse sequence ${ }^{9}$ methyl carbons $\left(\mathrm{CH}_{3}\right.$ and $\left.\mathrm{OCH}_{3}\right)$, aromatic $\mathrm{CH}$ and $\mathrm{CHO}$ show normaly phase positive signals while secondary $\left(>\mathrm{CH}_{2}\right)$ and quarternary $(>\mathrm{C}<)$ carbons show phase inverted signals. On the basis of these results and the signal assignments of $\mathbf{I}$, signals for aliphatic carbons were assigned at $\delta 14.5\left(\mathrm{CH}_{3}\right), 55.4,55.9$, and $56.0\left(\mathrm{OCH}_{3}\right), 63.9\left(\mathrm{OCH}_{2}\right), 74.2\left(\mathrm{CH}_{2}-\beta\right), 191.0$ and 191.7 (CHO), and 192.4 (CO).
By combining the data obtained from ${ }^{13} \mathrm{C}$ NMR, DEPT, and PENDANT spectra with those of $2 \mathrm{D}{ }^{1} \mathrm{H} /{ }^{13} \mathrm{C}$ - COSY contour plot it was possible to assign the aromatic hydrogenated carbons for each A, B, and C rings of trimers I and II. ${ }^{1} \mathrm{H} /{ }^{13} \mathrm{C}$ - COSY data are summarized in Table 4.

${ }^{1} \mathrm{H}$ NMR spectra of trimers III and IV were analyzed using the ${ }^{1} \mathrm{H}$ NMR spectra of both compounds I and II as a reference. This leads to assignments of hydrogens in trimers III and IV. The results are summarized in Table 5.

In addition, the presence of a hydroxymethyl group in trimer III was verified by comparing chemical shifts of trimer II (Table 1) with those of trimer III (Table 5). This group was characterized by signals at $\delta 4.87\left(\mathrm{CH}_{2} \mathrm{OH}\right)$ and $\delta 4.81\left(\mathrm{CH}_{2} \mathrm{OH}\right)$. As for trimers I and II, the ${ }^{13} \mathrm{C}$ chemical shift assignments for compounds III and IV were deduced from ${ }^{13} \mathrm{C}$ NMR spectra with help of the corresponding DEPT spectra and ${ }^{1} \mathrm{H} /{ }^{13} \mathrm{C}$ - COSY.

The ${ }^{13} \mathrm{C}$ spectrum of trimer III exhibited signals for aliphatic carbons at $\delta 14.6\left(\mathrm{CH}_{3} \mathrm{CH}_{2}\right), 55.3,55.7$, and 55.9 $\left(\mathrm{OCH}_{3}\right), 64.0\left(\mathrm{CH}_{3} \mathrm{CH}_{2} \mathrm{O}\right), 62.5\left(\mathrm{OCHCH}_{2} \mathrm{OH}\right), 83.8$

Table 4. Heteronuclear correlation $\left({ }^{1} \mathrm{H} /{ }^{13} \mathrm{C}-\mathrm{COSY}\right)^{*}$ for trimers I and II

\begin{tabular}{|c|c|c|c|c|c|}
\hline Trimer & Ring & $\mathrm{C}-2 / \mathrm{H}-2$ & C-5 / H-5 & C-6 / H-6 & $\mathrm{CHO}$ \\
\hline & A & $111.6 / 7.57$ & & $126.6 / 7.55$ & $192.7 / 9.94$ \\
\hline \multirow[t]{3}{*}{ I } & B & $113.3 / 7.60$ & & $126.3 / 7.38$ & $192.3 / 9.92$ \\
\hline & $\mathrm{C}$ & $111.1 / 7.33$ & $112.4 / 6.97$ & $123.3 / 7.47$ & \\
\hline & A & $109.2 / 7.39$ & & $128.0 / 7.36$ & $191.0 / 9.74$ \\
\hline \multirow[t]{2}{*}{ II } & B & $111.3 / 7.54$ & & $126.6 / 7.45$ & $191.7 / 9.92$ \\
\hline & $\mathrm{C}$ & $110.1 / 7.30$ & $111.4 / 6.95$ & $122.5 / 7.44$ & \\
\hline
\end{tabular}

*at $100 \mathrm{MHz}$ and DMSO-d 6

Table 5. ${ }^{1} \mathrm{H}$ Chemical Shifts $(\delta)$ of trimers III and IV

\begin{tabular}{|c|c|c|c|c|c|c|}
\hline \multirow{2}{*}{$\begin{array}{l}\text { Trimer } \\
\text { Group }\end{array}$} & \multicolumn{3}{|c|}{ III } & \multicolumn{3}{|c|}{ IV } \\
\hline & $\delta$ & Multip. & $J(\mathrm{~Hz})$ & $\delta$ & Multip. & $J(\mathrm{~Hz})$ \\
\hline $\mathrm{OCH}_{2} \mathrm{CH}_{3}$ & 1.36 & $\mathrm{t}$ & 7.0 & 1.26 & $\mathrm{t}$ & 7.0 \\
\hline $\mathrm{OCH}_{3}-\mathrm{A}$ & 3.88 & s & & 3.81 & s & \\
\hline $\mathrm{OC}_{3}-\mathrm{B}$ & 3.61 & s & & 3.82 & s & \\
\hline $\mathrm{OCH}_{3}-\mathrm{C}$ & 3.75 & s & & 3.68 & $\mathrm{~s}$ & \\
\hline $\mathrm{OC}_{2} \mathrm{CH}_{3}$ & 4.10 & $q$ & 7.0 & $3.89-3.95$ & $\mathrm{~m}$ & \\
\hline $\mathrm{OC}_{2} \mathrm{CHOH}$ & & & & $3.89-3.95$ & $\mathrm{~m}$ & \\
\hline $\mathrm{OCH}_{2} \mathrm{CHOH}$ & & & & $4.38-4.43$ & $\mathrm{~m}$ & \\
\hline $\mathrm{CHC} \underline{H}_{2} \mathrm{OH}$ & 4.81 & d & 5.8 & & $\mathrm{~s}$ & \\
\hline $\mathrm{CHCH}_{2} \mathrm{OH}$ & 4.87 & s & & & & \\
\hline $\mathrm{CHCH}_{2} \mathrm{OH}$ & 5.54 & $\mathrm{t}$ & 5.8 & & & \\
\hline $\mathrm{H}-2-\mathrm{A}$ & $7.43 / 7.46$ & d & 2.0 & & & \\
\hline H-2 - B & 7.58 & d & 1.9 & & & \\
\hline $\mathrm{H}-2-\mathrm{C}$ & 7.30 & d & 1.8 & & & \\
\hline $\mathrm{H}-5-\mathrm{C}$ & 6.97 & d & 8.2 & & & \\
\hline H-6 - A & $7.43 / 7.46$ & d & 2.0 & & & \\
\hline H-6 - B & 7.33 & d & 1.9 & & & \\
\hline H-6 - C & 7.50 & dd & 1.8 and 8.2 & & & \\
\hline CHO-A & 9.73 & $\mathrm{~s}$ & & & & \\
\hline CHO-B & 9.89 & $\mathrm{~s}$ & & & & \\
\hline $\mathrm{ArC}_{2}{ }_{2} \mathrm{OH}$ & & & & $4.38-4.43$ & $\mathrm{~m}$ & \\
\hline $\mathrm{OH}$ & & & & $4.90-5.30$ & $\mathrm{~m}$ & \\
\hline $\mathrm{ArH}$ & & & & $6.64-7.74$ & $\mathrm{~m}$ & \\
\hline
\end{tabular}


$\left(\mathrm{OCHCH}_{2} \mathrm{OH}\right), 191.0$ and $191.7(\mathbf{C H O})$, and $194.1(\mathbf{C O})$. The ${ }^{13} \mathrm{C}$ spectrum of trimer IV presented signals for aliphatic carbons at $\delta 14.7\left(\mathrm{CH}_{3} \mathrm{CH}_{2} \mathrm{O}\right), 55.3,55.7$ and 55.8 $\left(\mathrm{OCH}_{3}\right), 62.6$ and $62.7\left(\mathrm{CH}_{2} \mathrm{OH}\right), 63.7\left(\mathrm{CH}_{3} \mathrm{CH}_{2} \mathrm{O}\right), 71.3$ $\left(\mathrm{OCH}_{2} \mathrm{CHOH}\right)$, and $78.0\left(\mathrm{OCH}_{2} \mathrm{CHOH}\right)$.

Table 6 summarizes the ${ }^{13} \mathrm{C}$ NMR chemical shifts of aromatic carbons in trimers I to IV. The chemical shifts of aromatic carbons for compound III were assigned by comparison with those of compound II, while those of aromatic carbons in trimer IV were determined by comparison with model compounds $\mathbf{1}$ and $\mathbf{2}$ (Figure 2) ${ }^{10,11}$. The chemical shift assignments for compoud IV were also deduced from the ${ }^{13} \mathrm{C}$ NMR spectrum with help of the corresponding DEPT spectra.

Table 7 shows the ${ }^{13} \mathrm{C}$ NMR chemical shifts for these three compounds. From these data it may be verified that aromatic carbons of rings $\mathrm{A}$ and $\mathrm{B}$ of trimer IV as well as those of parent compound $\mathbf{1}$ present very close chemical shifts. Similarly, the chemical shifts assigned to aromatic carbons of ring $\mathrm{C}$ are closely related to those of compound $\mathbf{2}$.

\section{Conclusions}

Trimeric lignin model compounds containing 5-5' and $\beta-O-4$ ' substructures were synthesized, successfuly, by way of acetyldehydrodivanillin and $\alpha$-bromo-3-methoxy-4ethoxyacetophenone. This paves the way for the synthesis of oligomeric lignin model compounds containing
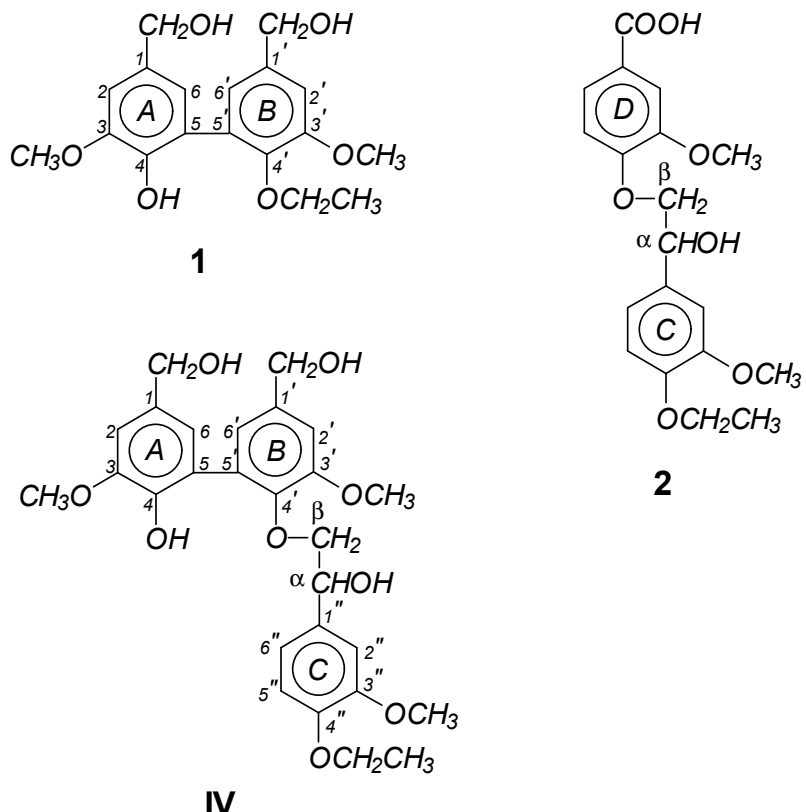

2

Figure 2. Model compounds related to IV.

biphenyl (5-5') and $\beta$-aryl ether ( $\left.\beta-O-4^{\prime}\right)$ substructures through Williamson's reaction.

The chemical shifts and coupling constants for I and II were deduced from 1D NMR spectra, and confirmed by $\mathrm{HMBC},{ }^{1} \mathrm{H} /{ }^{1} \mathrm{H}-\mathrm{COSY}$ and nOe difference spectra.

This last one was useful in establishing the conformation of 4-O-acetyl-4'-O-[ $\alpha$-(3-methoxy-4-ethoxyphenyl)-

Table 6. ${ }^{13} \mathrm{C}$ chemical shifts $(\delta)$ for aromatic carbons of trimers I - IV

\begin{tabular}{|c|c|c|c|c|c|c|c|}
\hline Trimers & ring & C-1 & $\mathrm{C}-2$ & $\mathrm{C}-3$ & C-4 & $\mathrm{C}-5$ & C-6 \\
\hline \multirow{4}{*}{ I } & A & 135.1 & 111.6 & 152.6 & 143.0 & 132.3 & 126.6 \\
\hline & B & 132.9 & 113.3 & 150.0 & 152.6 & 127.8 & 126.3 \\
\hline & $\mathrm{C}$ & 130.0 & 111.1 & 149.4 & 153.4 & 112.4 & 123.3 \\
\hline & A & 127.8 & 109.2 & 147.7 & 148.0 & 124.4 & 128.0 \\
\hline \multirow[t]{3}{*}{ II } & B & $131.6 *$ & 111.3 & 150.2 & 150.3 & 125.4 & 126.6 \\
\hline & $\mathrm{C}$ & $131.0 *$ & 110.1 & 148.5 & 152.5 & 111.4 & 122.5 \\
\hline & A & 127.8 & 109.2 & 140.8 & 148.3 & 124.0 & 128.6 \\
\hline \multirow[t]{3}{*}{ III } & B & 131.0 & 111.3 & 150.2 & 151.4 & 127.6 & 127.0 \\
\hline & $\mathrm{C}$ & 130.3 & 110.1 & 150.1 & 152.3 & 111.3 & 123.2 \\
\hline & A & 132.2 & 109.4 & 146.9 & 142.4 & 125.5 & 121.0 \\
\hline \multirow[t]{2}{*}{ IV } & B & 137.3 & 110.1 & 151.8 & 144.5 & 132.5 & 121.1 \\
\hline & $\mathrm{C}$ & 134.8 & 110.3 & 149.0 & 147.5 & 113.1 & 118.6 \\
\hline
\end{tabular}

$100 \mathrm{MHz}, \mathrm{DMSO}-d_{6}$, *these values may be exchangeable.

Table $7 .{ }^{13} \mathrm{C}$ NMR chemical shifts $(\delta)$ of trimer IV and dimers $\mathbf{1}^{10}$ and $\mathbf{2}^{11}$

\begin{tabular}{|c|c|c|c|c|c|c|c|}
\hline Compound & Ring & $\mathrm{C}-1$ & C-2 & $\mathrm{C}-3$ & C-4 & $\mathrm{C}-5$ & C-6 \\
\hline IV & $\mathrm{A}$ & 132.2 & 109.4 & 146.9 & 142.4 & 125.5 & 121.0 \\
\hline 1 & $\mathrm{~A}$ & 132.4 & 109.6 & 147.3 & 142.5 & 125.7 & 121.2 \\
\hline IV & B & 137.3 & 110.1 & 151.8 & 144.5 & 132.5 & 121.0 \\
\hline 1 & B & 137.3 & 110.2 & 152.5 & 144.4 & 133.0 & 121.2 \\
\hline IV & $\mathrm{C}$ & 134.8 & 110.3 & 148.5 & 147.5 & 112.6 & 118.2 \\
\hline 2 & $\mathrm{C}$ & 135.1 & 110.9 & 149.0 & 147.5 & 113.1 & 118.6 \\
\hline
\end{tabular}

$100 \mathrm{MHz}, \mathrm{DMSO}-d_{6}$ 
$\alpha$-oxoethyl]dehydrodivanillin (I). The results obtained show that the 3-methoxy-4-ethoxyphenacyl group is syn to ring $\mathrm{A}$ and also that ring $\mathrm{C}$ is rotating about $\mathrm{C}_{\alpha}-\mathrm{C}_{1}$, bond with no restriction. In addition, the analysis of nOe difference spectra has allowed to assign unambiguously the chemical shifts of hydrogens and methoxyl groups of each aromatic ring.

${ }^{1} \mathrm{H}$ NMR spectra of trimers III and IV were analyzed using the ${ }^{1} \mathrm{H}$ NMR spectra of both compounds I and II as a reference. As for trimers I and II, the ${ }^{13} \mathrm{C}$ chemical shift assignments for compouds III and IV were deduced from ${ }^{13} \mathrm{C}$ NMR spectra with help of the corresponding DEPT, ${ }^{1} \mathrm{H} /{ }^{13} \mathrm{C}$ COSY and HMBC spectra. While the chemical shifts of aromatic carbons for compound III were assigned by comparison with those of compound II, those of aromatic carbons in trimer IV were determined by comparison with dimeric model compounds.

From the $1 \mathrm{D}$ and $2 \mathrm{D}{ }^{1} \mathrm{H},{ }^{13} \mathrm{C}-\mathrm{NMR}$ spectroscopic studies of trimers $\mathbf{I}-\mathbf{I V}$, it is evident that the acetoxy group in trimer I undergoes base-catalyzed hydrolysis to give trimer II (Table 6). The later compound has a hydroxyl group at $\mathrm{C}-4$ of ring $\mathrm{A}$. This resulted in shielding $(\Delta \delta-2.9$ to $\Delta \delta$ - 7.9) of C-1, C-2, C-3 and C-5 and deshielding of $\Delta \delta+5.0$ and $\Delta \delta+1.4$ for $\mathrm{C}-4$ and $\mathrm{C}-6$ in ring $\mathrm{A}$, respectively. For ring $\mathrm{B}$, all aromatic carbons are shielded $(\Delta \delta-0.2$ to 2.4$)$. For ring C, C-1, C-2, C-4, and C-5 are shielded $(\Delta \delta-0.9$ to $\Delta \delta$ - 1.0).

Furthermore, chemical structures of trimers II and IV, differ in the substituents at C-1 of rings $\mathrm{A} / \mathrm{B}$ and at $\mathrm{C}-\alpha$ of side chain in ring C. As compared to trimer II, C-4 and C-6 of ring A of trimer IV are shielded by $\Delta \delta-5.6$ to -7.0 , while $\mathrm{C}-1$ and $\mathrm{C}-5$ are deshielded by $\Delta \delta+4.4$ and +1.1 , respectively. For ring B of $\mathbf{I V}, \mathrm{C}-2$ and $\mathrm{C}-4$ are shielded by $\Delta \delta$ - 1.2 and - 5.8, respectively, in addition to deshielding of C-1, C-3 and C-5 ( $\Delta \delta+1.6-5.7)$. For ring C of IV, C-4 and C-6 undergo shielding of $\Delta \delta-5.0$ and - 3.9, respectively, and C-1 deshielding of $\Delta \delta+3.8$.

\section{Acknowledgments}

This research project is supported by CNPq, FAPEMIG, and FINEP, for which the authors are grateful. This work constitutes part of the Doctoral Thesis of V.L. Alves.

\section{References}

1. Adler, E. Wood Science and Technol. 1977, 2, 169.

2. Lin, S. Y. Progress in Biomass Conversion 1983, 4,31 .

3. Drumond, M. G.; Aoyama, M.; Chen, C. -L.; Robert, D. J. Wood Chem. Technol. 1989, 9, 421.

4. Karhunen, P.; Rummakko, P.; Sipilä, J.; Brunow, G.; Kilpeläinen, I. Tetrahedron Lett. 1995, 36, 169.

5. Karhunen, P.; Rummakko, P.; Sipilä, J.; Brunow, G.; Kilpeläinen, I. Tetrahedron Lett. 1995, 36, 4501.

6. Karhunen, P.; Rummakko, P.; Pajunen, A.; Brunow, G. J. Chem. Soc. Perkin Trans. I 1996, 2303.

7. Ede, R. M.; Kilpeläinen, I. Res. Chem. Intermed. 1995, $21,313$.

8. Glasser, W. G.; Honeycutt, S. S.; Barnett, C. A.; Morohoshi, N. Tappi 1979, 62, 111.

9. Homer, J.; Perry, M. C. J. Chem. Soc., Chem. Commun. 1994, 373.

10. Drumond, M. G.; Piló-Veloso, D.; Cota, S. D. S.; Morais, S. A. L.; Nascimento, E. A.; Chen., C. -L. Holzforschung 1992, 46, 127.

11. Hassi, H.Y.; Aoyama, M.; Tai, D.; Chen, C. -L.; Gratzl, J. S. J. Wood Chem. Technol. 1987, 7, 551.

Received: September 1, 1998 Published on the web: August 31, 2000 